\title{
ECOLOGICAL ASSESSMENT OF PLANT COMMUNITIES ALONG THE EDAPHIC AND TOPOGRAPHIC GRADIENTS OF BIHA VALLEY, DISTRICT SWAT, PAKISTAN
}

\author{
IQBAL, Z. ${ }^{1}-$ ZEB, A. ${ }^{1}-$ ABD_Allah, E. F. ${ }^{2}-$ RAHMAN, I. U. ${ }^{1,3^{*}, \dagger}-$ KHAN, S. M. ${ }^{4}-$ ALI, N. ${ }^{1}-$ \\ IJAZ, F. ${ }^{1}$-ANWAR, Y. $^{5}$ - MUZAMMIL, S. ${ }^{5}-$ AlQARAWI, A. A. ${ }^{2}$ - HASHEM, A. ${ }^{6}-$ AFZAL, A. ${ }^{1}-$ \\ MAJID, A. ${ }^{1}-$ Khan, M. A. ${ }^{1}-$ CALIXTo, E. S. ${ }^{7}$ \\ ${ }^{1}$ Department of Botany, Hazara University, Mansehra-21300, KP, Pakistan \\ ${ }^{2}$ Department of Plant Production, College of Food \& Agricultural Sciences, King Saud University, P.O. Box \\ 2460, Riyadh 11451, Saudi Arabia
}

${ }^{3}$ William L. Brown Center, Missouri Botanical Garden, P.O. Box 299, St. Louis, MO 63166-0299, USA

${ }^{4}$ Department of Plant Sciences, Quaid-i-Azam University, Islamabad, Pakistan

${ }^{5}$ Department of Biological Sciences, Faculty of Science, King Abdulaziz University, Jeddah 21589, Saudi Arabia

${ }^{6}$ Botany and Microbiology Department, College of Science, King Saud University P.O. Box 2460, Riyadh 11451, Saudi Arabia

${ }^{7}$ Department of Biology, University of Sao Paolo, SP, Brazil

*Corresponding author

e-mail:hajibotanist@outlook.com; irahman@mobot.org

'ORCID ID: 0000-0003-3312-7975

(Received $21^{\text {st }}$ Feb 2018; accepted $2^{\text {nd }}$ Aug 2018)

\begin{abstract}
A study was conducted to explore the plant biodiversity and vegetation structure of Biha Valley, District Swat, Pakistan. On the basis of the physiognomy of the vegetation the study area was divided into 19 stands. Line transect $(50 \mathrm{~m})$ method was used to sample the phytosociological attributes of the study area. PCORD software (version 5) was used to recognize communities by two-way indicator species analysis (TWINSPAN) and CANOCO software (version 5) for ordination analysis was done for detrended correspondence analysis (DCA) and canonical correspondence analysis (CCA) to find variation directories of different plant species. Different life-form classes and leaf size spectra were recorded according to the Raunkiaer classification. The floristic composition of the area consists of 203 plant species belonging to 154 genera and 70 families. The biological spectrum of the area indicated that Therophytes was dominant with $46.60 \%$ among the life-classes, followed by Hemicryptophytes having $15.53 \%$. Leaf spectra of study area revealed that Microphylls was dominant $(41.26 \%)$ followed by Nanophylls $(32.04 \%)$. Seven plant communities were recognized by TWINSPAN classification, which showed that species diversity decreased with altitude. Moreover, the result indicates the importance of soil organic matter in top soil layers for plant species distribution. The increases in soil nutrients (OM, P, $\mathrm{N}$, and $\mathrm{K}$ ), improvement in site conditions (community cover, depth of litter, depth of humus, soil water content) and decrease in soil bulk density indicated the natural habitat restoration following abandonment. Keywords: multivariate analysis, similarity index, vegetation structure, biological spectrum, Pakistan
\end{abstract}

\section{Introduction}

Vegetation can be defined as the group of plants growing together in a particular locality. It can also be defined as a unit which retains their structure and physiognomic characteristics to permit their distinction from other units (Khan et al., 2012). Plants are 
common feature of the natural sceneries and grow in all environments. Though, each species being dispersed according to its own unique tolerance of a multitude of factors that consist its environment no species occur all over the world. Species with certain environmental tolerances develop into recognizable plant formations with distinctive floristic and structural characteristics. At a comprehensive scale these signify the major biomes of the world (Archibold, 1995). Vegetation of an area can either be characterized by its component species or by the functional combination and physical qualities that differentiate the physical appearance of vegetation. It is an essential variation that is illustrated by the different methods available for describing vegetation (Goldsmith et al., 1986; Kent and Coker, 1992). Floristic diversity and its biological spectra rely on topography and elevation. Plant-life characters like life form, leaf size spectra, and phenological traits mirror the conditions of the existing ecological and natural surroundings (Rahman et al., 2018).

Phytosociology is the study of the characteristics, classification, relationships and distribution of plant communities and attempts to describe the species diversity in plant communities (Haq et al., 2015a). It displays a high association between vegetation and environmental conditions, enabling us to discover, the complicated relations of ecosystem parts by studying resources and environment (Asri, 1994). Plants of similar nature and ecological needs (niche) are associated with each other, creating plant ecological groups (Braun-Blanquet, 1983). Plant communities include one or more ecological groups (Khademi, 2009). Phytosociology is a branch of plant ecology that explains the association of plant species in communities (Ewald, 2003). Plants type and characteristics of soil are so related that they cannot be isolated from of each other. Phytosociology is the quantitative study of vegetation and its prime purpose is to describe the vegetation its pattern and classify it in a meaningful method. It shows species diversity which determines the dispersal of individuals among the species in a specific habitat (Haq et al., 2015b). A number of quantitative, qualitative and synthetic characteristics of plant communities e.g. density, dominance, richness, floristic composition, structure, physical appearance, development and exchange multilateral relations of plants to one another and to the environmental factors and the classification of communities are examined by phytosociology.

To date, the Biha Valley (Swat) has not been studied using recently developed analytical methods for vegetation characterization. The current study was therefore carried out to document the floristic diversity of the area, to recognize the major plant communities of the site and to identify the key environmental variables influencing vegetation structure, species composition and species diversity in the research area.

\section{Materials and methods}

\section{Study area}

The study site (Biha Valley) is located in the northwestern part of District Swat in the Hindu Raj series of Hindukush Mountains (Fig. 1). The Valley is one of the Union councils of Tehsil Matta that comprises 22991 ha. It is situated in the North West corner of District Swat. It lies between $35^{\circ} 60$ and $35^{\circ} 20$ North latitude and $72^{\circ} 30$ to $72^{\circ} 40$ East longitude (Adnan, 2003). The valley is surrounded by Usherai Dara (Dir) from West, Dir Kohistan on the North, Shawar valley from the South West and Mandal dag, Charma and Sulatan valley from the Eastern North. Pushtoni, Nalkot, Biha, Fazal banda, Chatikal, Dughalgay and Swatai are the important villages situated in this area. 


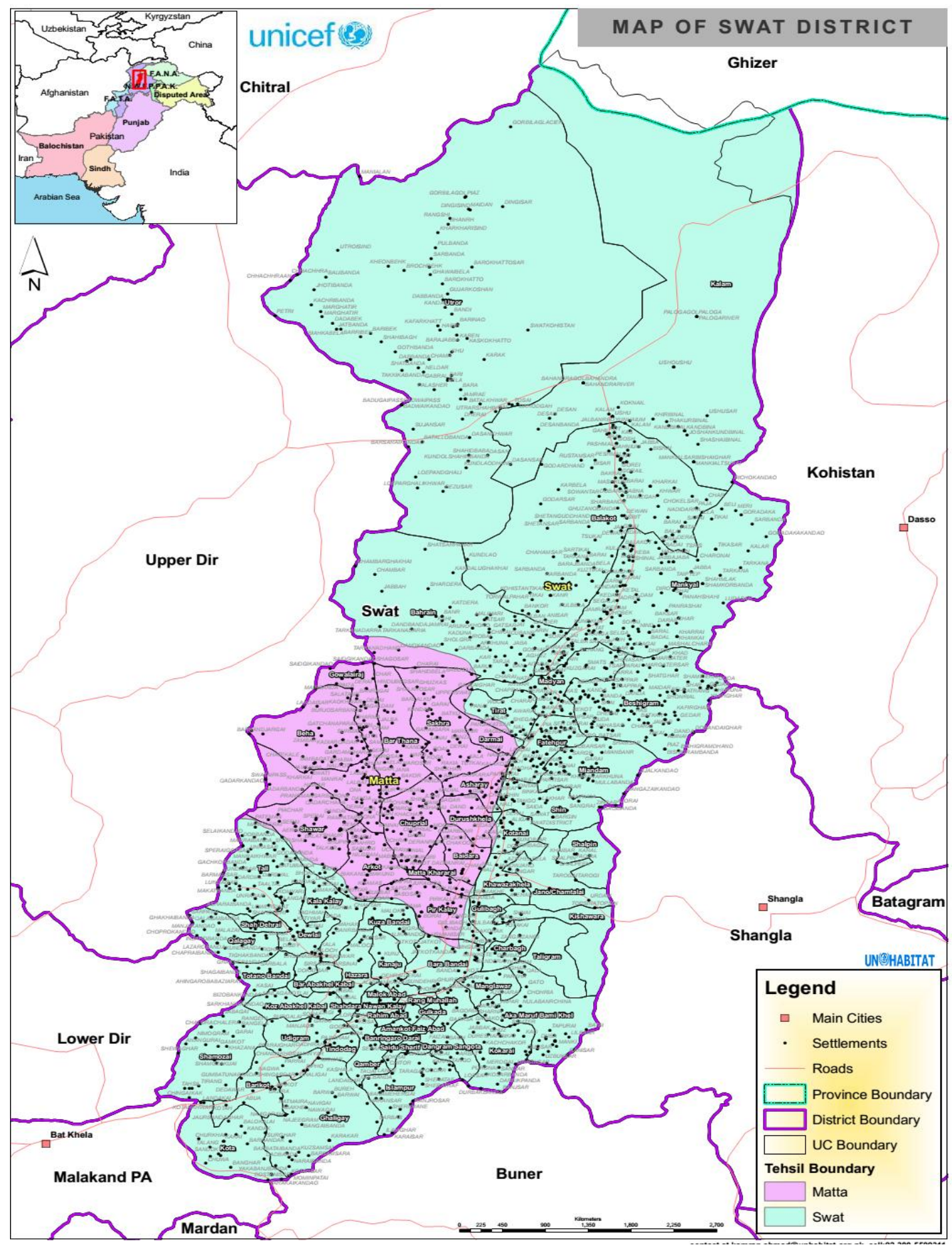

Figure 1. Map of the study area

\section{Natural vegetation}

The site has diverse vegetation setup and cool climatic condition in summer due to high elevation that varies from 1600 to $4100 \mathrm{~m}$ from sea level. Phyto-geographically, the study area lies in Sino-Japanese region (Ahmad and Sirajuddin, 1996). Vegetation of the area consists of moist temperate forests (Champion et al., 1965) extending to sub 
alpine and alpine types. The mountains along the valley are densely forested. The project area has unique flora as it occupies nexus of the three great mountains i.e. Landaysar, Brajosar and Datkor soki. Nature has been very generous to the region in its endowments of very tall invincible peaks, enormous glaciers, majestic streams, and the meadows of high altitude plateaus. Due to its geographical location within the monsoon belt, farmers of the lower parts of the area cultivate orchards, cereals as well as cash crops. In upper parts of the valley forests and alpine pastures prevail widely. Accordingly, the valley gives home to vast diversity of useful plants i.e. edible, medicinal and aromatic plants are common. Various products like honey, morels, and handicrafts are also obtained by the local people from the valley. Doghalgo khvar Chatikal and Swatai are the main streams which meet with each other in Biha Valley.

Regarding the altitude, climate, soil and topography, vegetation of Biha valley can be classified into the following broad categories:

1. Olive-White Oak Zone: These forests are located at lower altitudinal ranges from 1400 to $1700 \mathrm{~m}$ above sea level.

2. Blue Pine Zone: These forests can be observed between 1700 and $2700 \mathrm{~m}$ and represent the major part of vegetation in the valley. This type of vegetation is located in Derai sargay, Pakani, Yag bila and Cyakas etc.

3. Fir Spruce Zone: Fir spruce forests can be observed above $2700 \mathrm{~m}$ upto an elevation of $2900 \mathrm{~m}$ at Kotago, Kadyar, Kamali chari, Dolo, Jargogo and Jaby.

4. Tree Line Iron Oak Forest: These forests are usually located between 2900 and $3400 \mathrm{~m}$ at Goryal, Sangwano kandaow, Mero kandaow and Dat kor. However, in some areas these forests occur from $2750 \mathrm{~m}$ where they are usually mixed with fir and spruce at the lower boundary. These forests change to pure iron oak forest as the elevation increases.

5. Alpine and Sub-Alpine Zone: This type of vegetation can be observed above $3200 \mathrm{~m}$ and is present in Kandaw sar, Mero kandaow, Landay sar, Brajo sar, and Sangwano kandaow.

\section{Climate}

Climatically, the area comes under typical sub-tropical dry temperate zone. The subtropical, semi-arid climate of Saidu Sharif is comparable to that in the lower parts of the valley while the upper parts of the valley have a climate of temperate type up to $2500 \mathrm{~m}$ height and above $2500 \mathrm{~m}$ there is subalpine and alpine zone. Winter is hard and summer precipitation remains high at higher altitudes as compared to lower parts of the valley (Weiers, 1995). Monsoon winds (from subtropical regions of the Arabian Sea) bring summer rainfall while westerlies are responsible for winter rain and snowfall in the valley. Due to considerable precipitations in both seasons the upper regions of the Biha valley are comparatively much humid than the lower areas. June and July are the hottest months and December, January and February are the coldest months of the year. Relative humidity is also an important atmospheric factor governing the distribution of plants and vegetation (Hussain and Ilahi, 1991). The value of relative humidity is higher in the months of July, August and September. There are usually two rainy seasons per year: One lasts from January to April (winter rainfall and the other one occurs in July/August (summer rainfall). Snowfall frequently occurs from November to March. Coldest months of the year are December, January and February in which the valley remains permanently under snow cover. The lower snow line in winter in Doghalgay Valley is 1800 to $4000 \mathrm{~m}$. Beside rainfall and snowfall hailing, that damage the crops 
and orchards badly, is also common during May and June (summer) and September and October (autumn) (Khan, 1991). Relative humidity is also an important atmospheric factor governing the distribution of plants and vegetation (Hussain and Ilahi, 1991). The value of relative humidity is higher in the months of July, August and September.

\section{Rock types and soil}

The area is characterized by very complicated geological structures and rocks. Quartz and mica, with minor iron garnet or graphite etc are its major components. The rocks are usually dark grey with a micaceous shine on the surface. The main soil materials are silty clay loam and in moderately deep silt loam (Shangla-rockland complex), which is closely related to the parent rock. The area has different parent rocks therefore wide variety of soil types can be found in the area.

\section{Field investigations}

The entire study area was surveyed to identify the different stands of vegetation on the basis of the physiognomy of the vegetation. The Geological Positioning System (GPS) coordinates including altitude, longitude and latitude were taken from each stand by using GPS. Line transect method by using $50 \mathrm{~m}$ transect was used to sample the phytosociological attributes of the study area (Kent and Coker, 1992). Density, cover, frequency, relative density, relative cover and relative frequency for each species was calculated following Daubenmire (1959) and Hussain (1989). Phenology of the species was documented by visiting the study area in different intervals during 2012-2013. Different life-form classes and leaf size spectra were recorded according to the Raunkiaer classification.

\section{Community homogeneity}

Similarity Index determines the interspecific association between the species of plant communities. The index of similarity was calculated after Sorenson (1948) by using the following formula (Eq. 1):

$$
S I=2 C / A+B \times 100
$$

where, $\mathrm{C}=$ the least importance value of common species, $\mathrm{A}=$ importance value of community $\mathrm{A}, \mathrm{B}=$ importance value of community $\mathrm{B}$.

Dissimilarity Index is the reverse sequence of similarity index. It was calculated by using the following formula (Eq. 2):

$$
I D=100-I S
$$

where, Is = Index of similarity and S = Sorenson Index.

\section{Soil analyses}

For soil analysis, the soil will be dugout, the surface soil up to $10 \mathrm{~cm}$ depth was removed and about $500 \mathrm{~g}$ of soil from each sample was collected, mixed well individually before the use and analyzed in the soil laboratory at ARI (Agriculture research institute) Mingora, Swat, Pakistan. Then samples were air dried at 20 to $25{ }^{\circ} \mathrm{C}$, 
and passed through a $2 \mathrm{~mm}$ sieve and analyzed for different physiochemical characteristics. Soil $\mathrm{pH}$ and texture were measured with the help of dynamic digital pH meter and hydrometer respectively (McLean, 1982; Koehler et al., 1984; Rahman et al., 2015, 2017). Nitrogen through Macro-Kjeldahl method (Paul and Berry, 1921), Phosphorus and Potassium were analyzed through ammonium bicarbonate-diethylene triamine penta acetic acid (AB-DTPA) method (Soltanpour and Woekman, 1979). While, soil organic matters were determined by following Nelson et al. (1996).

\section{Data analyses}

The data were statistically analyzed to find out the relationship between plant species composition and different physiographic and edaphic attributes. PCORD software (version 5) was used to recognize communities by two-way indicator species analysis (TWINSPAN) and CANOCO software (version 5) for ordination analysis was done for detrended correspondence analysis (DCA) and canonical correspondence analysis (CCA) to find variation directories of different plant species (Ter Braak, 1986, 1994).

\section{Results}

\section{Floristic composition}

The study area consists of 203 plant species belonging to 70 different families and 154 genera. The biggest family was Asteraceae consisting of 19 species, while the other major families were Rosaceae comprising of 16 species.

\section{Flowering stage}

During field observations in the research area two flowering seasons were recorded. The first flowering seasons were observed from May to August, in which total 174 species $(85.35 \%)$ were observed in flowering and in peak flowering period. The species included herbs $(71.41 \%)$, shrubs $(11.83 \%)$, trees $(10.65 \%)$, ferns $(2.37 \%)$ with prominent sori (reproductive phase) and climbers were present with $1.78 \%$. While in the second spell (September to October) only 29 plant species with $14.65 \%$ were observed in flowering stage in which $62.07 \%$ were herbs, $13.79 \%$ shrubs, $10.34 \%$ trees and $6.90 \%$ grasses and ferns each. The flowering stage of the plants starts to decline from 15 October in the Alpine areas and continues from the middle of November in the lower sub-tropical regions. The remaining $80 \%$ of the plants were in either fruiting stage or dormant condition and remain dormant till April (Table 1). The distribution of flowering species showed significant variations with altitude. Plants living at high elevations especially in alpine and sub-alpine areas were found in blooming condition from July to August while plants at lower altitude were found in blooming condition from May to July.

Table 1. Flowering seasons of plant species recorded in the Biha Valley

\begin{tabular}{c|c|c|c|c|c|c|c|c|c|c|c|c|c|c}
\hline Season & \multicolumn{2}{|c|}{ Herbs } & \multicolumn{2}{c|}{ Shrubs } & \multicolumn{2}{c|}{ Trees } & \multicolumn{2}{c|}{ Grasses } & \multicolumn{2}{|c|}{ Ferns } & \multicolumn{2}{c|}{ Climber } & \multicolumn{2}{c}{ Total } \\
\hline May-Aug & 122 & $71.4 \%$ & 20 & $11.8 \%$ & 18 & $10.6 \%$ & 5 & $2.3 \%$ & 6 & $2.9 \%$ & 3 & $1.8 \%$ & 174 & $85.3 \%$ \\
\hline Sep-Oct & 17 & $62.1 \%$ & 4 & $13.8 \%$ & 3 & $10.3 \%$ & 3 & $6.9 \%$ & 2 & $6.9 \%$ & 0 & 0 & 29 & $14.6 \%$ \\
\hline
\end{tabular}




\section{Fruiting stage}

The main fruiting period of the study area was recorded from September onward, 185 plant species $(91.41 \%)$ were observed in fruiting stage while from May to August the poorest fruiting period was recorded during which only 18 plants species $(8.59 \%)$ were observed (Table 2).

Table 2. Fruiting seasons of plant species recorded in the Biha Valley

\begin{tabular}{|c|c|c|c|c|c|c|c|c|c|c|c|c|c|c|}
\hline Season & \multicolumn{2}{|c|}{ Herbs } & \multicolumn{2}{|c|}{ Shrubs } & \multicolumn{2}{|c|}{ Trees } & \multirow{2}{*}{\multicolumn{2}{|c|}{$\begin{array}{c}\text { Grasses } \\
0\end{array}$}} & \multirow{2}{*}{\multicolumn{2}{|c|}{$\begin{array}{c}\text { Ferns } \\
0\end{array}$}} & \multirow{2}{*}{\multicolumn{2}{|c|}{$\begin{array}{c}\text { Climbers } \\
0\end{array}$}} & \multicolumn{2}{|c|}{ Total } \\
\hline May-Aug & 16 & $88.2 \%$ & 1 & $5.9 \%$ & 1 & $5.9 \%$ & & & & & & & 18 & $8.6 \%$ \\
\hline Sep onward & 123 & $67.4 \%$ & 23 & $12.7 \%$ & 20 & $11.1 \%$ & 8 & $3.3 \%$ & 8 & $3.8 \%$ & 3 & $1.7 \%$ & 185 & $91.4 \%$ \\
\hline
\end{tabular}

\section{Phytosociology}

\section{TWINSPAN classification}

The phytosociological data of 19 stands having 203 species were analyzed by TWINSPAN Classification. In this classification a total of seven plant communities were recognized in the study area (Fig. 2). These communities are described below.

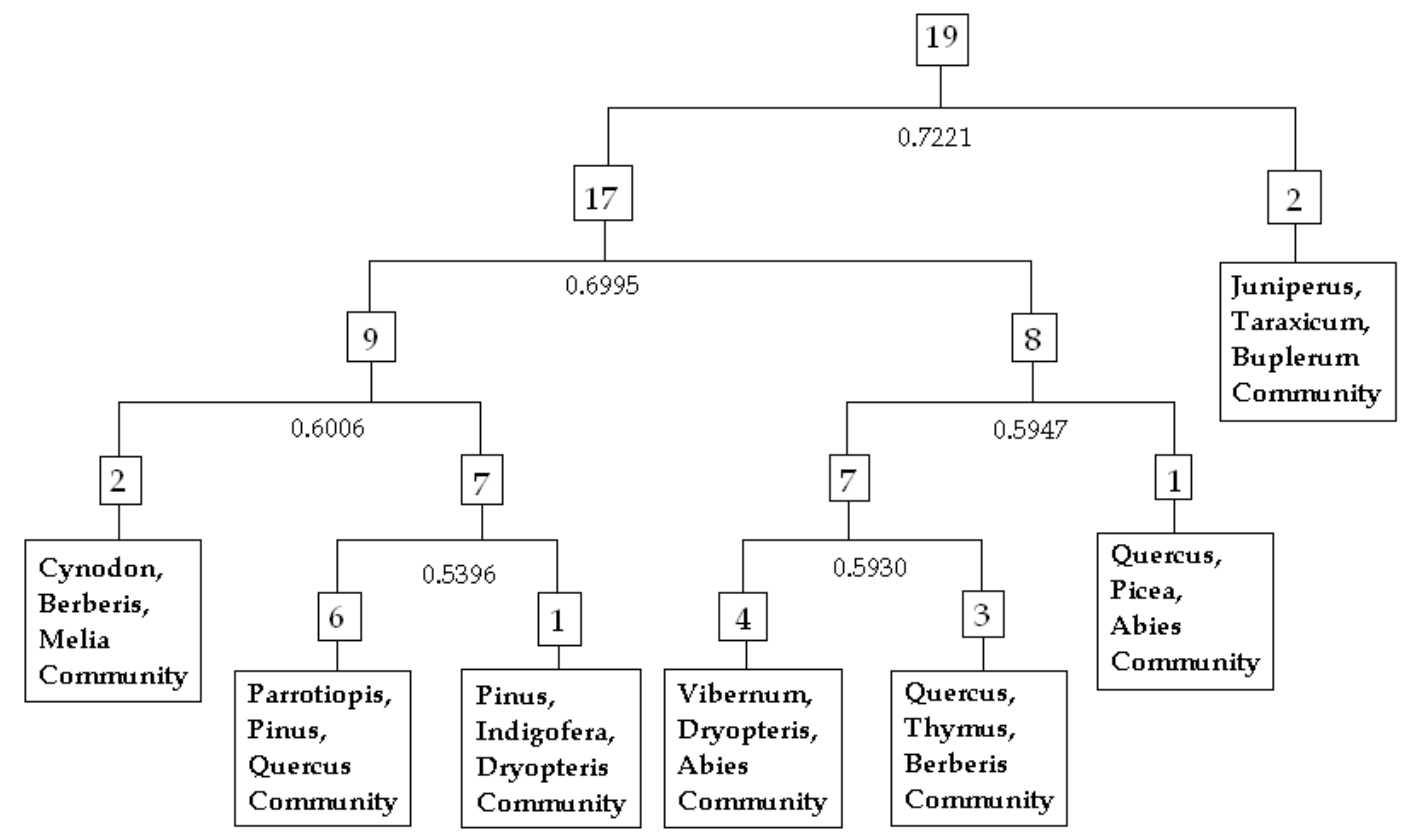

Figure 2. TWINSPAN classification of plant communities of the Biha Valley

\section{The Cynodon-Berberis-Melia (CBM) community}

This community was recorded at Nalkot sarbira and Nalkot shigartan from longitude $\left(\mathrm{E}=072^{\circ} 18.127^{\prime}\right.$ to $\left.072^{\circ} 18.127^{\prime}\right)$ and latitude $\left(\mathrm{N}=35^{\circ} 03.516^{\prime}\right.$ to $\left.35^{\circ} 04.080^{\prime}\right)$ from north-east to south exposure with $15^{\circ}$ to $30^{\circ}$ slope at $5174-5445 \mathrm{ft}$ elevation. The community consists of 70 plant species including 43 herb species, 12 species of shrubs and trees each, 2 grass species and 1 fern species. The dominant species in this 
community was Cynodon dactylon with 32.97 IVI the co-dominant species were Berberis lyceum with 13.83 IVI and Melia azadarach with 12.92 IVI. In the community, 135.07 IVI contributed by herbs, 68.06 by trees, 61.96 by shrubs, 36.28 by grasses and 0.95 by ferns (Table 3). Therophytes was the dominant life form in the community (40\%) followed by Nanophanerophytes (17.14\%). Microphylls was the dominant leaf spectra in the community (52.86\%) followed by Nanophylls (24.29\%). This community existed in loamy sand soil with basic nature $(\mathrm{pH}=7.2$ to 7.6$)$. The organic matter in the soil was 2.90 to $4.28 \%$, nitrogen was 0.14 to $0.21 \%$. Phosphorous was 6.67 to $7.86 \mathrm{mg} / \mathrm{kg}$, potassium was 132 to $138 \mathrm{mg} / \mathrm{kg}$ and electric conductivity was 0.03 to 0.09 .

Table 3. Numbers and total importance value contributed by herbs, shrubs and trees in each community of the Biha Valley

\begin{tabular}{|c|c|c|c|c|c|c|c|}
\hline S. no & CBM & PPQ & PID & VDA & QTB & QPA & JTB \\
\hline Altitude (ft) & $5174-5445$ & $5606-7503$ & 7078 & $7557-8850$ & $9450-10513$ & 10345 & $11225-11760$ \\
\hline Latitude & $\begin{array}{l}072^{\circ} 18.127^{\prime}- \\
072^{\circ} 18.127^{\prime}\end{array}$ & $\begin{array}{l}072^{\circ} 17.397^{\prime}- \\
072^{\circ} 16.852^{\prime}\end{array}$ & $072^{\circ} 13.501^{\prime}$ & $\begin{array}{l}072^{\circ} 13.224^{\prime}- \\
072^{\circ} 12.207\end{array}$ & $\begin{array}{l}072^{\circ} 11.899^{\prime}- \\
072^{\circ} 11.608^{\prime}\end{array}$ & $072^{\circ} 14.678$ & $\begin{array}{l}072^{\circ} 15.842^{\prime}- \\
072^{\circ} 15.586^{\prime}\end{array}$ \\
\hline Longitude & $\begin{array}{l}35^{\circ} 03.516^{\prime}- \\
35^{\circ} 04.080^{\prime}\end{array}$ & $\begin{array}{l}35^{\circ} 02.675^{\prime} \\
35^{\circ} 03.456^{\prime}\end{array}$ & $35^{\circ} 05.626^{\prime}$ & $\begin{array}{l}35^{\circ} 05.776^{\prime}- \\
35^{\circ} 06.240^{\prime}\end{array}$ & $\begin{array}{l}35^{\circ} 06.284^{\prime}- \\
35^{\circ} 06.567\end{array}$ & $35^{\circ} 08.546^{\prime}$ & $\begin{array}{c}35^{\circ} 08.224^{\prime}- \\
35^{\circ} 8.292^{\prime}\end{array}$ \\
\hline Slope angle & $15^{\circ}$ to $30^{\circ}$ & $28^{\circ}$ to $40^{\circ}$ & $20^{\circ}$ & $22^{\circ}$ to $33^{\circ}$ & $24^{\circ}$ to $49^{\circ}$ & $31^{\circ}$ & $20^{\circ}$ to $27^{\circ}$ \\
\hline $\begin{array}{c}\text { Slope } \\
\text { exposure }\end{array}$ & $\begin{array}{l}\text { North-east to } \\
\text { south }\end{array}$ & $\begin{array}{c}\text { S/E, N/W. N/E, } \\
\text { E and N }\end{array}$ & South-west & $\begin{array}{l}\text { South-east and } \\
\text { North-east }\end{array}$ & $\begin{array}{l}\text { North-east and } \\
\text { South-east }\end{array}$ & South & $\begin{array}{l}\text { South-east and } \\
\text { North-east }\end{array}$ \\
\hline Herbs species & 43 & 58 & 22 & 26 & 31 & 17 & 22 \\
\hline Shrubs species & 12 & 19 & 4 & 2 & 6 & 1 & 2 \\
\hline Trees species & 12 & 11 & 2 & 7 & 3 & 3 & 0 \\
\hline Grass species & 2 & 2 & 1 & 0 & 0 & 0 & 3 \\
\hline Fern species & 1 & 5 & 2 & 4 & 1 & 0 & 1 \\
\hline Climbers & 0 & 3 & 0 & 0 & 0 & 0 & 0 \\
\hline $\begin{array}{c}\text { IVI of first } 3 \\
\text { dominant } \\
\text { species }\end{array}$ & 59.72 & 50.23 & 107.73 & 97.93 & 80.49 & 113.15 & 98.18 \\
\hline $\begin{array}{c}\text { By remaining } \\
\text { species }\end{array}$ & 212.6 & 218.32 & 220.45 & 204.09 & 225.65 & 186.85 & 201.81 \\
\hline Herbs IVI & 135.07 & 112.58 & 170.37 & 126.37 & 191.2 & 159.14 & 212.09 \\
\hline Shrubs IVI & 61.96 & 82.88 & 52.65 & 39.86 & 43.93 & 18.13 & 60.12 \\
\hline Trees IVI & 68.06 & 44 & 42.64 & 87.92 & 68.33 & 113.15 & - \\
\hline Grasses IVI & 36.28 & 3.31 & 8.41 & - & - & - & 23.58 \\
\hline Ferns IVI & 0.95 & 22.29 & 39.90 & 47.87 & 2.68 & - & 4.2 \\
\hline Climbers IVI & - & 3.49 & - & - & - & - & - \\
\hline
\end{tabular}

$\mathrm{CBM}=$ Cynodon-Berberis-Melia, $\mathrm{PPQ}=$ Parrotiopsis-Pinus-Quercus, $\mathrm{PID}=$ Pinus-Indigofera-Dryopteris, VDA = VibernumDryopteris-Abies, QTB = Quercus-Thymus-Berberis, QPA = Quercus-Pieacea-Abies, JTB = Juniperus-Taraxicum-Bupleurum

\section{The Parrotiopsis-Pinus-Quercus (PPQ) community}

From 5606 to $7503 \mathrm{ft}$ altitude, Parrotiopsis, Pinus and Quercus community was found in More Khwar, Koza Pakani, Bara Pakani, Sarma Pakanai, Pakani Shaheed and Wale Drab locality. The longitude of the community varies from $\mathrm{E}=072^{\circ} 17.397^{\prime}$ to $072^{\circ} 16.852^{\prime}$ and latitude $\mathrm{N}=35^{\circ} 02.675^{\prime}$ to $35^{\circ} 03.456^{\prime}$ on $\mathrm{S} / \mathrm{E}, \mathrm{N} / \mathrm{W}, \mathrm{N} / \mathrm{E}, \mathrm{E}$ and $\mathrm{N}$ exposures with $28^{\circ}$ to $40^{\circ}$ slope degree. The community comprised of 98 plant species out of which 58 species were herbs, 19 species were shrubs, 11 species were trees, 5 species were ferns, 3 species were climbers and 2 species were grasses. In this 
community Parrotiopsis jacquemontiana was the dominant species with 17.33 IVI while the co-dominant species were Pinus wallichiana 16.47 and Quercus incana with 16.43 IVI. In the community the herbs contributed a total of 112.58 IVI, 82.88 by shrubs, 44 by trees, 22.29 by ferns, 3.49 by climbers and 3.31 by grasses (Table 3). The dominant life form class in the community was Therophytes $(44.44 \%)$ followed by Nanophanerophytes (17.17). The dominant leaf spectrum in the community was Microphylls (45.45\%). The loamy sand soil of this community had basic nature ( $\mathrm{pH}=$ 6.8 to 7.8 ) in comparison with other communities. The organic matter in the soil was noted 0.69 to $4.14 \%$ and nitrogen was 0.03 to $0.21 \%$. The total amount of phosphorous found in the soil was 5.75 to $14.11 \mathrm{mg} / \mathrm{kg}$, potassium was 112 to $162 \mathrm{mg} / \mathrm{kg}$ and electric conductivity was 0.02 to 0.08 .

\section{The Pinus-Indigofera Dryopteris (PID) community}

At $7078 \mathrm{ft}$ elevation, Pinus-Indigofera-Dryopteris was observed in Yag bila/Chatikal $\mathrm{E}=072^{\circ} 13.501^{\prime} . \mathrm{N}=35^{\circ} 05.626^{\prime}$ on the southwest facing with $20^{\circ}$ slope. The community consists of 31 plant species out of which 22 species were herbs 4 species were shrubs, 2 species were ferns and trees each, and 1 species was grass. The dominant species in this community was Pinus wallichiana with IVI 37.38 while the associated species were Indigofera heterantha (36.34) and Dryopteris blonfordii with 34.0 IVI. In this community 170.37 IVI contributed by herbs, 52.65 by shrubs, 42.64 by trees, 39.90 by ferns and 8.41 by grasses (Table 3 ). The dominant life form class in this community was Hemicryptophytes (35.71\%) followed by Therophytes $(32.14 \%)$. Based on the leaf spectra the community is categorized in Microphylls (39.29\%). The soil chemistry of the community was loamy sand and had a $\mathrm{pH}$ of 7 . The organic matter in the soil was the lowest as compared to other communities (1.04\%) while nitrogen was $0.05 \%$, phosphorous was the highest in the soil $(19.57 \mathrm{mg} / \mathrm{kg})$. Potassium was $158 \mathrm{mg} / \mathrm{kg}$ and electric conductivity was 0.03 of the soil.

\section{The Vibernum-Dryopteris-Abies (VDA) community}

Vibernum grandiflorum, Dryopteris blonfordii and Abies pindrow community was recorded from 7557 to $8850 \mathrm{ft}$ elevation in Jarogo jai, Jarogo khwargai, Jarogo banda and Goryal jai $072^{\circ} 13.224^{\prime}$ to $072^{\circ} 12.207^{\prime} \mathrm{E}$ and $35^{\circ} .05 .776^{\prime}$ to $35^{\circ} 06.240^{\prime} \mathrm{N}$ on the south-east and north-east facing slope with $22^{\circ}$ to $33^{\circ}$. The community consists of 39 plant species out of which 26 species were herbs, 7 species were trees, 4 species were ferns and 2 species were shrubs. The highest IVI in community was of Viburnum grandiflorum with 39.13 while the associated species were Dryopteris blonfordii 29.43 and Abies pindrow with 29.38 IVI. In this community a total of 126.37 IVI was contributed by herbs 87.92 by trees 47.87 by ferns and 39.86 by shrubs (Table 3 ). In this community the Therophytes was the dominant life form (41.03\%), followed by Hemicryptophytes (25.64\%). On the basis of leaf spectra, the community is characterized by Microphylls (30.77\%), Nanophylls (25.64\%), Mesophylls (20.51\%), Leptophylls (15.38\%) and Megaphyll (7.69\%). The physico-chemical analysis showed that the community was established in pure loamy to loamy sand soil with pH highly acidic slightly neutral 6 to 7.2. Organic contents in the soil were observed (1.73 to $4.83 \%$ ) the highest in comparison with other communities and nitrogen was 0.09 to $0.17 \%$. Phosphorous was measured 6.14 to $13.12 \mathrm{mg} / \mathrm{kg}$, potassium was 112 to 164 $\mathrm{mg} / \mathrm{kg}$ and electric conductivity was 0.01 to 0.14 . 


\section{The Quercus-Thymus-Berberis (QTB) community}

At 9450 to $10513 \mathrm{ft}$ altitude, Goryal 1, Goryal 2 and Kandaow locality $072^{\circ} 11.899^{\prime}$ to $072^{\circ} 11.608^{\prime} \mathrm{N}$ and $35^{\circ} 06.284^{\prime}$ to $35^{\circ} 06.567^{\prime} \mathrm{E}$ on northeast and southeast exposures with $24^{\circ}$ to $49^{\circ}$ slopes, the community Quercus semicarpifolia, Thymus linearis and Berberis jaeschkeana was recorded. The community contains 41 plant species out of which 31 species were herbs, 6 species were shrubs, 3 species were trees and 1 species was fern. In this community Quercus semicarpifolia was the dominant species with 41.83 IVI while the co-dominant species were Thymus linearis 19.52 and Berberis jaeschkeana with 19.14 IVI. In the community the herbs contributed a total of 191.2 IVI, trees 68.33, shrubs 43.93, and ferns 2.68 (Table 3). The dominant life form in the community was Therophytes $(43.90 \%)$ followed by Hemicryptophytes $(19.51 \%)$. The dominant leaf spectrum in the community was Microphylls (43.90\%), Nanophylls (29.27\%), Leptophylls (12.20\%), Mesophylls (9.76\%) and Megaphyll (4.88\%). The soil chemistry of the community was loamy sand with highly acidic nature to neutral of 5.8 to $7 \mathrm{pH}$. The organic content in the soil was observed 2.42 to $4.14 \%$, whereas the nitrogen was 0.12 to $0.21 \%$. The amount of phosphorous was measured high as compared to other communities (6.14 to $19.67 \mathrm{mg} / \mathrm{kg}$ ), potassium was 138 to $160 \mathrm{mg} / \mathrm{kg}$ and electric conductivity was observed 0.02 to 0.12 .

\section{The Quercus-Picea-Abies (QPA) community}

At an altitude of $10345 \mathrm{ft}$, Quercus semicarpifolia, Picea smithiana and Abies pindrow community was recorded in Mero kandaow locality $\mathrm{E}=072^{\circ} 14.678^{\prime}, \mathrm{N}=35^{\circ}$ $08.546^{\prime}$ on south facing slope with $31^{\circ}$. The community comprised of 21 plant species out of which 13 species were herbs, 3 species were trees and 1 species was a shrub. In this community Quercus semicarpifolia was the dominant species with 57.97 IVI while the co-dominant species were Picea smithiana 28.66 and Abies pindrow with 26.52 IVI. In the community the herbs contributed a total of 159.14 IVI, trees 113.15 and shrubs 18.13 (Table 3). The dominant life form in the community was Therophytes (47.62\%) followed by Hemicryptophytes (19.05\%). The dominant leaf spectrum in the community was Microphylls (47.62\%). The physiochemical analysis of the soil showed that this community was present in loamy sand soil with a highly basic character $(\mathrm{pH}=$ 8) in comparison with other communities. The organic matter in the soil was noted $2.42 \%$ and nitrogen was $0.12 \%$. The total amount of phosphorous found in the soil was $7.33 \mathrm{mg} / \mathrm{kg}$, potassium was $156 \mathrm{mg} / \mathrm{kg}$ and electric conductivity was 0.01 .

\section{The Juniperus-Taraxacum-Bupleurum (JTB)}

The community was observed at Landay sar and Sali kandaow of Dughalgo side at longitude $\mathrm{E}=072^{\circ} 15.842^{\prime}$ to $072^{\circ} 15.586^{\prime}$ and latitude $\mathrm{N}=35^{\circ} 08.224^{\prime}$ to $35^{\circ} 08.292^{\prime}$ of the area on southeast and northeast exposures with $20^{\circ}$ to $27^{\circ}$ slope at 11225 to $11760 \mathrm{ft}$ elevation. The community comprised of 28 plant species having 22 species of herbs 3 species of grasses 2 species of shrubs and 1 species of ferns. In this community, Juniperus communis has the highest importance value index 45.07 followed by the codominant species Taraxacum officinale and Bupleurum longicaule having 34.2 and 18.91 importance value index respectively. A total of 212.09 importance value index was contributed by herbs 60.12 by shrubs, 23.58 by grasses and 4.2 by ferns (Table 3). The major life form in the community observed was Therophytes $(50 \%)$ followed by Chamaephytes (25\%). The highest leaf spectra observed in the community was 
Nanophyll (32.14\%), followed by Microphyll (28.57\%). Physico-chemical analysis showed that the soil of the area was pure loamy to loamy sand with acidic nature of 5.8 to $6 \mathrm{pH}$. The organic matter noted was 2.76 to $4.83 \%$ and nitrogen was 0.14 to $0.24 \%$ in the soil of the community while phosphorous was 6.93 to $8.38 \mathrm{mg} / \mathrm{kg}$ and potassium was the highest as compared to other communities 144 to $186 \mathrm{mg} / \mathrm{kg}$. The electric conductivity (EC) of the community was also high in comparison with other communities 0.52 to 0.67 .

\section{Index of similarity (IS)}

The highest index of similarity $(50.63 \%)$ was recorded between Vibernum grandiflorum, Dryopteris blonfordii, Abies pindrow, and Quercus semicarpifolia, Thymus linearis and Berberis jasckeana communities followed by (48.57\%) between Pinus wallichiana, Indigofera heterantha, Dryopteris blonfordii and Vibernum garndiflorum, Dryopteris blonfordii Abies pidrow communities (36.68\%) between Cynodon dactylon, Berberis lycium, Melia azadarch and Parrotiopsis jacquemontiana, Pinus wallichiana, Quercus incana communities. Intermediate similarity was recorded (27.77\%) between Pinus wallichiana, Indigofera heterentha, Dryopteris blonfordii and Quercus semicarpifolia, Thymus linearis and Berberis jasckeana communities (27.53\%) between Parrotiopsis jacquemontiana, Pinus wallichiana, Quercus incana and Vibernum garndiflorum, Dryopteris blonfordii Abies pidrow communities (26.15\%), Parrotiopsis jacquemontiana, Pinus wallichiana, Quercus incana and Pinus wallichiana, Indigofera heterantha, Dryopteris blonfordii. The highest index of similarities ranges from $26.15 \%$ to $50.63 \%$ between communities due to same conditions of soil such as soil texture, organic matter and $\mathrm{pH}$ and physiographic factors such as slope angle, slope exposure and less difference in altitude. The least similarity index $(2.02 \%)$ was noted between Cynodon dactylon, Berberis lycium, Melia azadarch and Juniperus communis, Taraxacum officinale, Bupleurm longicaule communities. Remaining communities also showed less than $20 \%$ similarity due to variation in altitude (5350 to $12000 \mathrm{ft}$ ), soil condition, organic matter, $\mathrm{pH}$ and phosphorus percentage (Table 4).

Table 4. Similarity and dissimilarity index

\begin{tabular}{c|c|c|c|c|c|c|c}
\hline Community & CBM & PPQ & PID & VDA & QTB & QPA & JTB \\
\hline CBM & $\mathrm{X}$ & 36.68 & 19.80 & 14.67 & 11.88 & 6.52 & 2.04 \\
PPQ & 63.32 & $\mathrm{X}$ & 26.15 & 27.53 & 15.71 & 9.91 & 3.14 \\
PID & 80.2 & 73.85 & $\mathrm{X}$ & 48.57 & 27.77 & 11.32 & 3.38 \\
VDA & 85.33 & 72.42 & 51.43 & $\mathrm{x}$ & 50.63 & 19.67 & 2.98 \\
QTB & 88.12 & 84.29 & 72.23 & 49.37 & $\mathrm{X}$ & 19.06 & 11.59 \\
QPA & 93.48 & 90.09 & 88.68 & 80.33 & 80.94 & $\mathrm{X}$ & 4 \\
JTB & 97.96 & 96.86 & 96.62 & 97.02 & 88.41 & 96 & $\mathrm{X}$ \\
\hline
\end{tabular}

$\mathrm{CBM}=$ Cynodon-Berberis-Melia, $\mathrm{PPQ}=$ Parrotiopsis-Pinus-Quercus, $\mathrm{PID}=$ Pinus-IndigoferaDryopteris, VDA = Vibernum-Dryopteris-Abies, QTB = Quercus-Thymus-Berberis, QPA = QuercusPieacea-Abies, JTB = Juniperus-Taraxicum-Bupleurum

\section{Index of dissimilarity (ID)}

According to Muller-Dumbois and Ellenberg (1974), plant communities having less than $65 \%$ similarity were considered as dissimilar. All the plant communities of the 
investigated area showed less than $65 \%$ similarity hence considered as different communities. The highest dissimilarity $(97.96 \%)$ was recorded between Juniperus communis, Taraxacum officinale, Bupleurm longicaule and Cynodon dactylon, Berberis lycium, Melia azadarch communities (97.02\%), between Juniperus communis, Taraxacum officinale, Bupleurm longicaule and Vibernum garndiflorum, Dryopteris blonfordii Abies pidrow communities (96.86\%), between Juniperus communis, Taraxacum officnale, Bupleurm longicaule and Parrotiopsis jacquemontiana, Pinus wallichiana, Quercus incana communities (96.62\%), Juniperus communis, Taraxacum officnale, Bupleurm longicaule and Pinus wallichiana, Indigofera heterentha, Dryopteris blonfordii while the lowest dissimilarity (49.37\%) was observed between Quercus semicarpifolia, Thymus linearis and Berberis jasckeana and Vibernum grandiflorum, Dryopteris blonfordii, Abies pindrow communities (51.43\%), between Vibernum garndiflorum, Dryopteris blonfordii Abies pidrow and Pinus wallichiana, Indigofera heterentha, Dryopteris blonfordii and Vibernum garndiflorum. All the other communities have greater than $60 \%$ dissimilarity (Table 4).

\section{Ordination}

Ordination of species

All species of the 19 stands and 7 communities were analyzed through Detrended Correspondence Analysis DCA which showed that the species of Cynodon dactylon and Melia azadarch, Oenothera rosea and Dactylis glumerata, Diospyros lotus and Celtis caucasica, Spirea canescens and Trifolium repens, Quercus dilatata and Berberis lycium, Pinus wallichiana and Indigofera heterentha, Achyranthes aspera and Quercus incana, Abies pindrow and Rumex dentatus, Anemone obtusiloba and Viola canescens, Bupleurum longicaule and Rumex nephalensis, Epilobium hirsutum and Juniperus communis have positive correlation with each other. While the species of Juglans regia and Quercus semicarpifolia, Beberis lycium and Juniperus communis, Diospyros lotus and Piecea smithiana, Rubus fruticosus and Barberis jaeschkena have negative correlation with each other and Bistorta amplexicaulis was found an isolated species as no correlated species was found with it (Fig. 3).

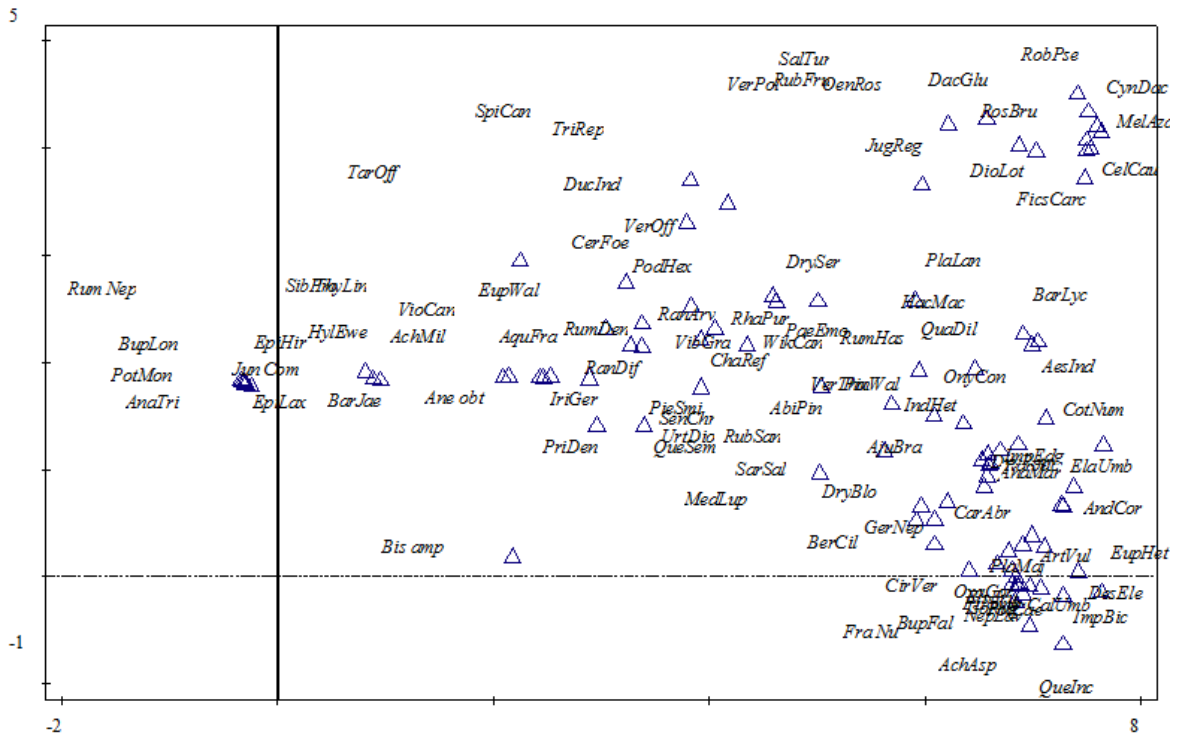

Figure 3. DCA ordination of species 


\section{Ordination of stands}

The ordination of all stand of the study area given Detrended Correspondence Analysis DCA (Fig. 4). The DCA of stand indicated that both stands 1 and 2 correlated with each other, stand 3,12,13,14, 15 and 16 correlated as well, 5, 6, 7 and 8 correlated too, 9, 10 and 11 also correlated, 17 and 19 correlated as well with each other in environmental variables and similar vegetation while stand 4 and stand 18 have no correlation with any stand therefore, these are considered as individual communities.

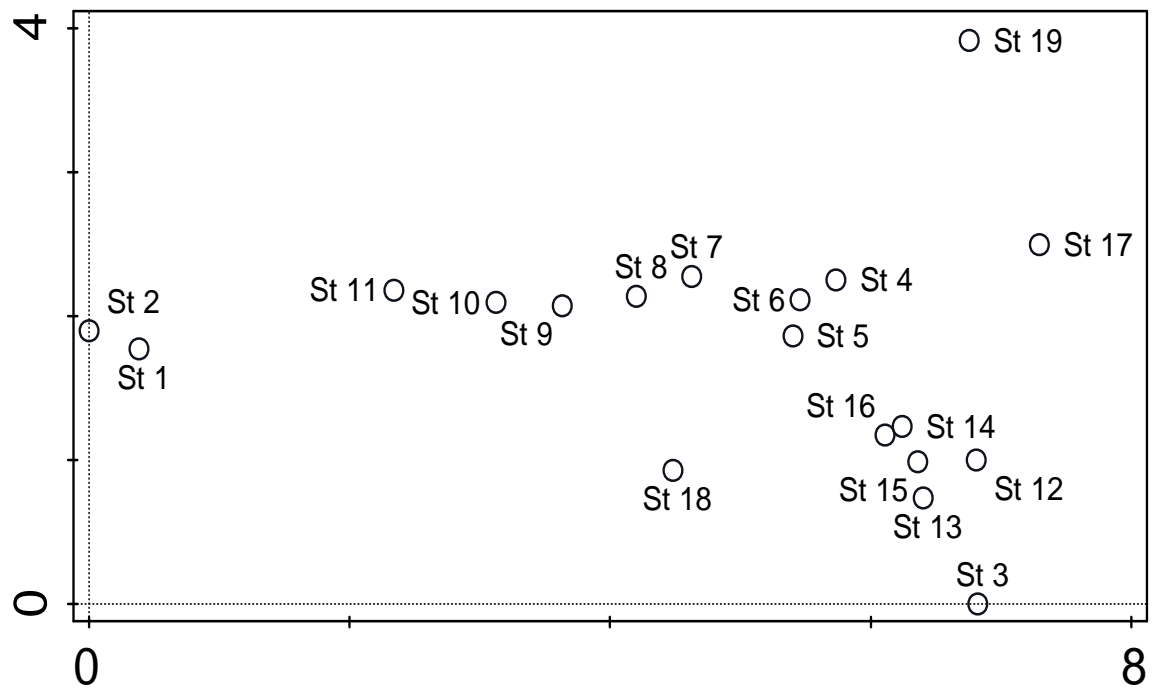

Figure 4. DCA ordination of stands

\section{Ordination of species with environmental variables}

The correlation between vegetation and environmental variables was indicated in the ordination diagram produced through Canonical Correspondence Analysis (CCA). In which the direction and length of the arrow indicated the environmental variables and the triangle shaped clusters indicated the vegetation while length of the arrow shows the strength of variable between the variable at each axis representing the degree of correlation between them, the variables on the same axis show positive correlation while the variables on the opposite axes indicated negative correlation. As shown in (Fig. 5) that Abies pindrow, Verbena officinalis and Rumex dentatus were highly correlated with slope steepness while these species were less correlated with electric conductivity, silt, soil fertility, $\mathrm{pH}$, latitude and soil classes. Viburnum grandiflorum, Trifolium repens, Duchesnea indica, Primula denticulate, Sibbaldia procumbens, Viola canescens, Anemone obtusiloba, were highly correlated with phosphorous and less correlated with silt, latitude, electric conductivity, $\mathrm{pH}$, and classes. Barberis jaeschkena, Taraxacum officinale and Hylotelephium ewersii were highly correlated with potassium and less correlated with classes, $\mathrm{pH}$, latitude, silt, and electric conductivity. Similarly, Trachydium roylei, Bupleurum longicaule, Genetiana olivieri, Eritrichuim canum, Anaphalis triplenervis, Bergenia stracheyi, Cerastium pusillum, Circea cordata and Potentella Monenthes have close association with electric conductivity and nitrogen and less relationship with slope angle, slope facing, phosphorous and potassium. Chenopodium album, Calamintha umbrosa, Elscholtzia fruticosa, Baberis lyceum, Andrachne cordifolia and Desmodium elegans were closely associated with latitude and 
less associated with slope steepness, altitude, longitude, slope exposure, clay, soil fertility, potassium and phosphorous. Carpesium abrotonoide, Artemisia vulgaris and Elaeagnus umbellate were highly associated with $\mathrm{pH}$ and less correlated with altitude, longitude clay, slope exposure and slope steepness. No species was found closely associated with altitude and longitude however the density of species decreases with the increase in altitude.

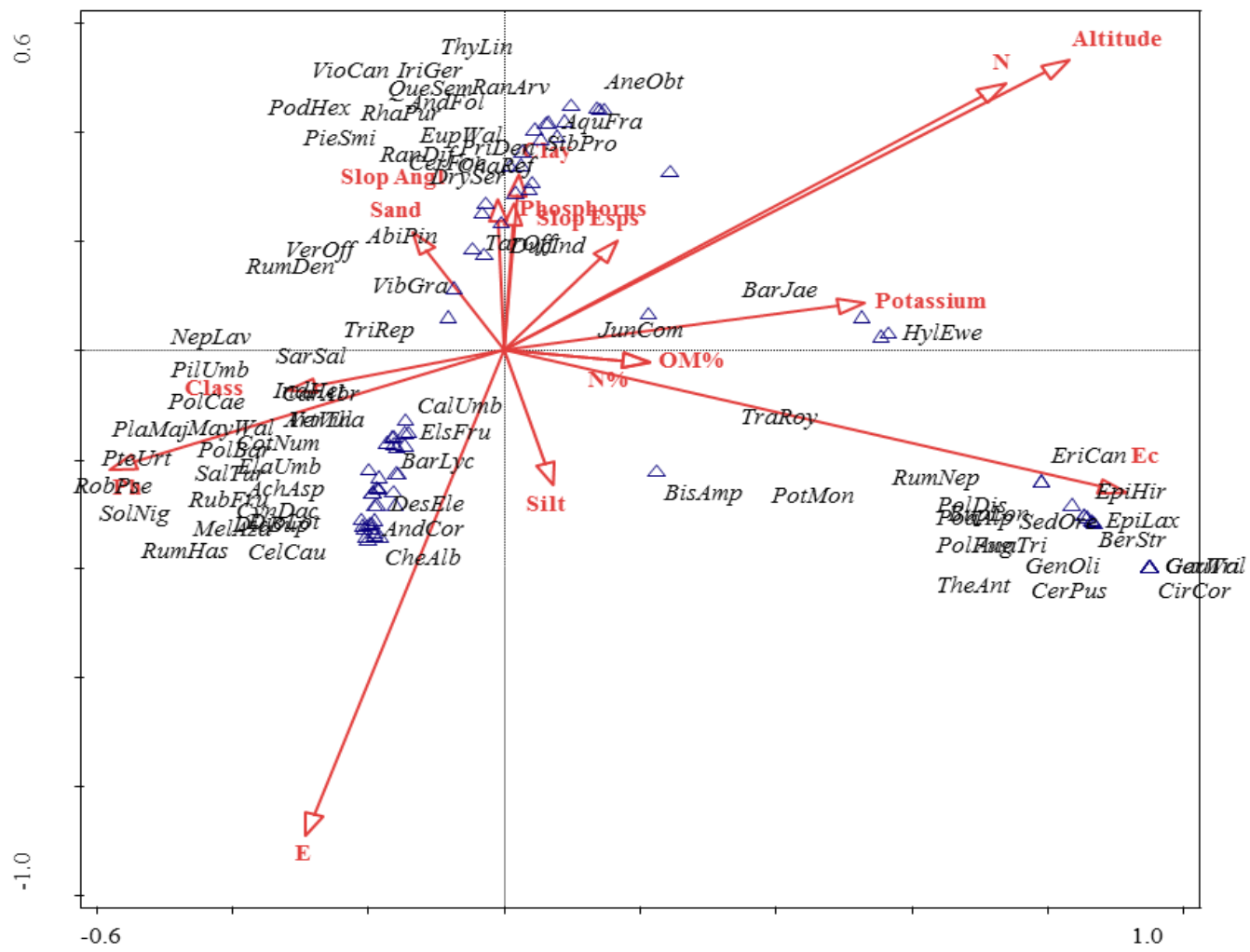

Figure 5. CCA ordination of species with environmental variables

\section{Ordination of communities with environmental variables}

CCA ordination was used to find the correlation of environmental variables and plant communities of the study area (Fig. 6). The maximum strength was recorded for the environmental variables like altitude, electric conductivity and nitrogen. The minimum environmental variable strength was recorded for Organic matter. The stands of Cyanodon, Berberis, Melia community and Parrotiopsis, Pinus, Quercus community positively correlated with Latitude and $\mathrm{pH}$. Pinus, Indigofera, Dryopteris community positively correlated with sand. Vibernum, Dryopteris, Abies community positively correlated with sand, slope angle, clay and phosphorous. Quercus, Thymus, Berberis community were positively correlated with slope aspect, clay and phosphorous. Quercus, Picea, Abies community positively correlated with slope angle and clay. The stands of Juniperus, Taraxacum, Bupleurum community positively correlated with electrical conductivity. In constrained CCA ordination the total variation was 5.859, explanatory variables account for $84.5 \%$. The CCA ordinations of different axis are given in Table 5. 


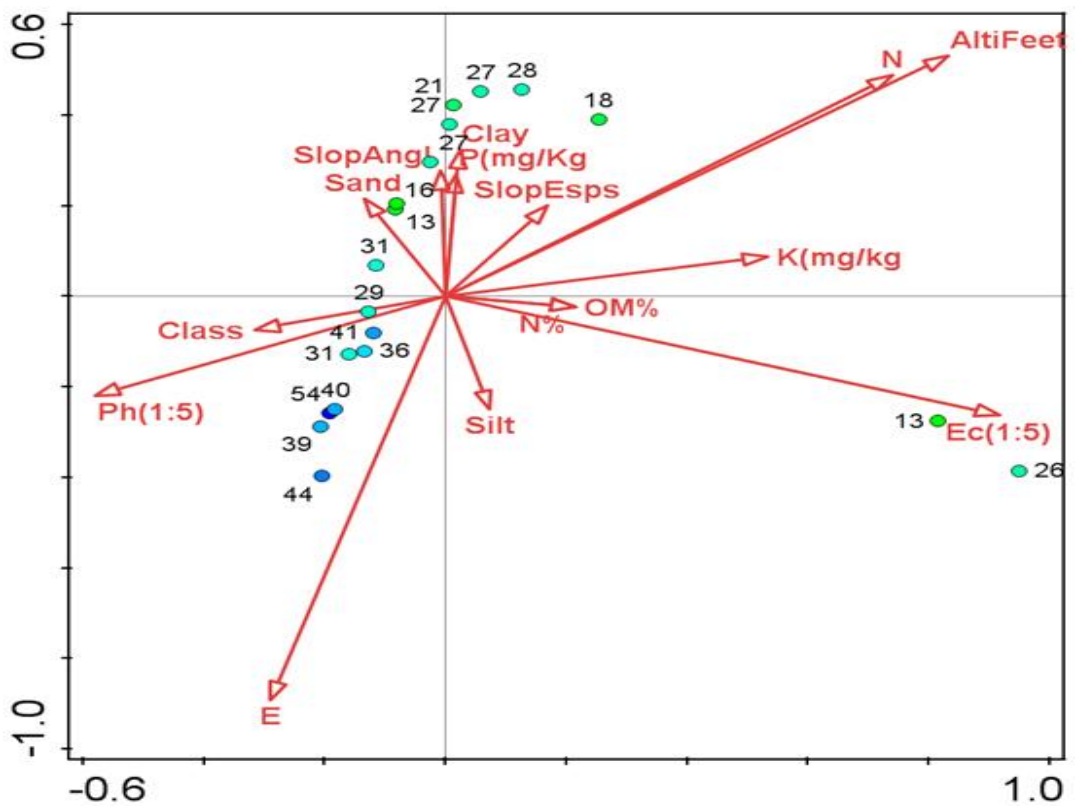

Figure 6. CCA ordination of stands with environmental variables

Table 5. CCA ordination on different axis

\begin{tabular}{c|c|c|c|c}
\hline Statistic & Axis 1 & Axis 2 & Axis 3 & Axis 4 \\
\hline Eigenvalues & 0.8393 & 0.7068 & 0.5418 & 0.4799 \\
\hline Explained variation & 14.32 & 26.39 & 35.63 & 43.82 \\
\hline Pseudo-canonical correlation & 0.9982 & 0.9979 & 0.9976 & 0.9561 \\
\hline Explained fitted variation & 16.94 & 31.21 & 42.15 & 51.84 \\
\hline Permutation test results: on all axes & \multicolumn{4}{|c}{ Pseudo-F $=1.1, \mathrm{P}=0.256$} \\
\hline
\end{tabular}

\section{Discussion}

In the present study a sum of 203 plants species of 70 families were recorded in which the leading families were Asteraceae, Rosaceae and Lamiaceae; therefore, the area was considered rich floristically. Our results are in accordance with previous reports of many researchers of the country. Ijaz (2016) and Khattak et al. (2015) mentioned Asteraceae while Rahman et al. (2016a, b) cited Lamiaceae as the leading families from their study areas. During the present study the ratio of flowering was found different at different time of the year. A very few herbaceous and shrubby plants initiated vegetative growth at the end of April. Early May is the blooming time for few plant species. Plant species such as Juglans regia, Melia azaadarch, Morus alba, Rosa moschata, Rubus fruticosus, Caltha alba and Lactuca dissecta were active during this period. May to August is the favorable season for the flowering for the majority of shrubby, trees and herbaceous species. July and August were the peak flowering months after that flowering stage starts declining. Similarly, Zhanghe et al. (1999) also described that peak of flowering happened during May in various parts of China.

The study of characteristics, classification, relationships and distribution of plant communities is known as phytosociology (Dastagir et al., 1999). From elevation of $5174 \mathrm{ft}$ to $12760 \mathrm{ft} 7$ different plant communities were established from 19 stands with 
203 plant species in the study area by using TWINSPAN classification. Seasonal fluctuations and sampling time change the structure of the community which is the consequence of the environmental conditions, habitat and existing vegetation types. Champion et al. (1965) and Bano et al. (2018) recognized different communities of plants from various areas and reported that it was due to the degradation of environmental and anthropogenic factors therefore the current investigation also signify that the major vegetation units were degraded by different environmental variables and man-made factors. Kumar (1996) found the relation between species distribution and soil physical factors like soil moisture and texture and El-Ghani (1998) reported a close relationship between soil chemistry $(\mathrm{pH})$, calcium and organic carbon and composition of plant species. Organic matter content as a pivotal soil fertility factor can affect phytodiversity (Zhang et al., 2010). Our results indicate the importance of soil organic matter in top soil layers for plant species distribution. The increases in soil nutrients (OM, P, N, and K), improvement in site conditions (community cover, depth of litter, depth of humus, soil water content) and decrease in soil bulk density indicated the natural habitat restoration following abandonment.

DCA and Cluster analysis are very useful in plant communities and classification of species and other than this to give structure to plant life. Soil $\mathrm{pH}$, texture and density of trees are the major causes of vegetation pattern (Saima et al., 2009).

The ranges of altitude have an important effect on qualitative and quantitative characteristics of trees (Fallah Chay and Marvie, 2005). The mean of temperature, evaporation and transpiration are reducing with increasing altitude range, while the humidity will be increasing. Some species of plants do not prefer the high altitudes because of short growth period and low temperatures. The presence of severe winds in highlands also confines the growth of plant. At lower altitude $(5445 \mathrm{ft})$ of the study area Cynodon-Berberis-Melia community exists while the Parrotiopsis-Pinus-Quercus was present at 5606 to $7503 \mathrm{ft}$ elevation; similarly, at high elevation of 10000 to $12000 \mathrm{ft}$ the Quercus-Thymus-Berberis community and Juniperus-Taraxacum-Bupleurum community was recorded. Agreed findings were reported by Bano et al. (2018). They recorded the presence of Berberis community at 2485-2937 m. Similarly, Thymus and Artemisia community is reported by Aleyha and Shokuii (2003) at 2350-2500 m elevation in Semnan. Karimi (1997) documented the Thymus and Agropyron community in Anzali-Khalkhal area at 1400 to1800 m altitude. The elevation in the area showed positive correlation with the number of species. Our findings are in line with Dasti and Malik (1998) who indicated that altitude is an environmental variable which affects the density and association of plants. Our results reveal that soil characteristics such as electric conductivity, $\mathrm{pH}$, clay and fertility have great effect on community distribution and plants species association.

The results revealed that slope exposure was one of the most important variable influencing the plant distribution. South and north facing slopes have completely unlike vegetation covers. South facing slopes have high temperature and low humidity because of severe solar radiation in comparison with north facing slopes. In contrast, north facing slopes have low temperature and has high humidity because of low radiation. As the community of Juniperus -Taraxacum and Bupleurum exists on northeast facing slopes and at lesser altitude such a situation is resulted from the deficit of radiation and temperature. Vibernum-Dryopteris and Abies community was recorded also in north facing slopes. While on south facing slope Cynodon-Berberis and Melia community was recorded at lower altitude and Quercus-Picea and Abies 
community was observed at high elevation. According to Nazarian (2003), the Salix community was present in north-northeast facing slopes, and the thorny assemblages on south, southwest, southeast, north, northwest and northeast facing slopes in Central Alborz. In our investigation direction of east and west slope were only found effective on growth of diameter and north exposure was found effective on species richness, canopy cover and species association (Fig. 7). The analysis of site exposure is commonly used for the determination of qualitative and quantitative indices (Corney et al., 2006; Ajbilou et al., 2006).

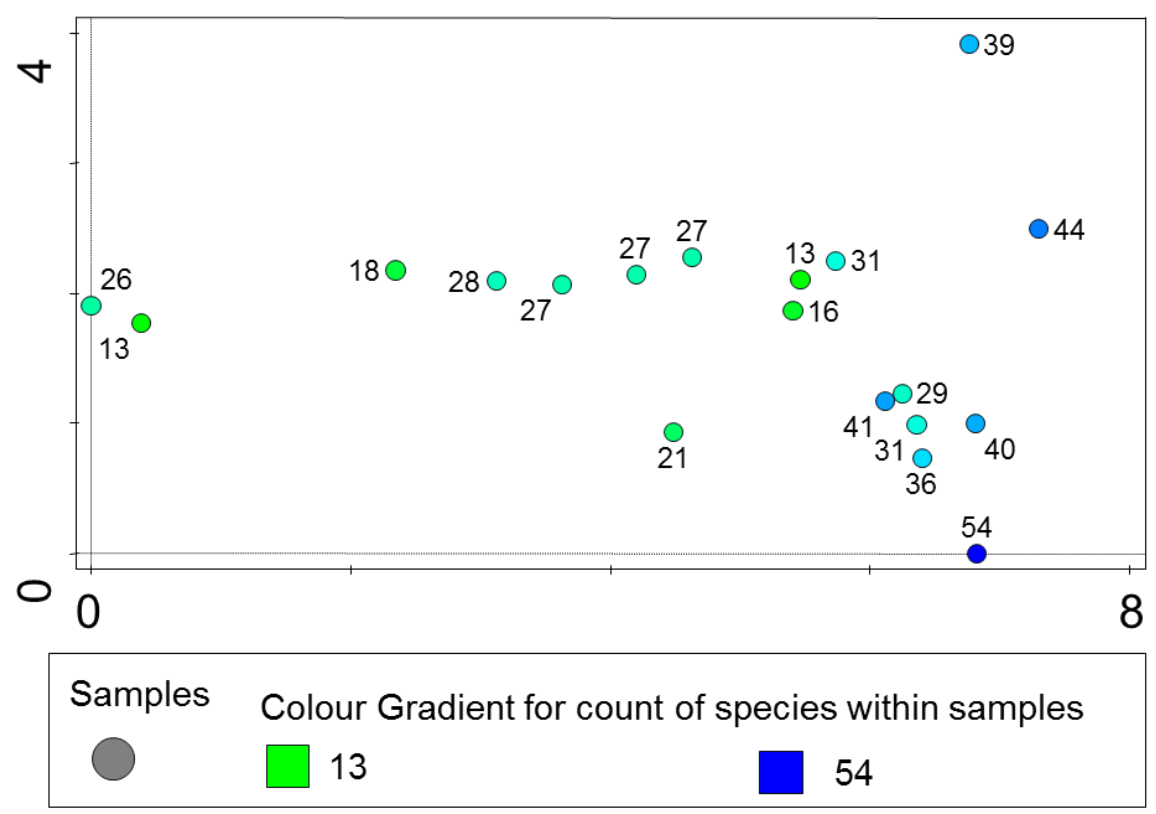

Figure 7. DCA ordination showing the taxonomic richness of species

Slope angle or steepness influences the cover of vegetation on different kinds of slopes. In the studied area, Cyanodon as a grass, Pinus community as a tree and Juniperus as a shrub accumulation are present on moderate slopes, but Parrotiopsis, Vibernum as a shrub Quercus and Quercus as tree communities are stretched on sharp slopes. Khageaddin in (2000) described the existence of Amygdalus haussknechtii on high slopes of more than 100\% in Kolah ghazi National Park.

The distribution and composition of plant communities in the studied area seems to be controlled by different environmental variables together with climate, topography, soil and biotic pressure. These variables go through variations of various points due to relations with each other and may possibly result in micro-gradients (Hanson and Churchill, 1965). The soil characteristics also influence the distribution of plant on smaller scale (Bakkenes et al., 2002). Landscape also plays significant role in physical features of vegetation. It influences the plant life by changing other variables of environment. Diverse aspects, slopes and altitudes support various plant communities in Biha Valley. Similar findings were recorded by Ahmed et al. (2009) during their research work on Olea ferruginea forests of lower Dir. 


\section{Conclusion}

The present investigated area has rich phytodiversity containing 203 plant species including 137 herbs, 25 shrubs, 21 trees, 8 grasses, 8 ferns and 3 species of climbers. Most of the local inhabitants are depending upon the biodiversity of the area. The local people use plant resources for various purposes including medicinal, for fodder, fruits, vegetables, fuel wood etc. The dominance of Therophytes and Microphylls type of biological spectrum shows that the area has sub-tropical and moist temperate type of climate. The ecological characters of plants such as density, frequency and abundance were completely influenced by the natural as well as biotic pressures mainly at the sites of the investigation area. The highest values of density and frequency were observed in the rainy season and the minimum values in the cold season. Plants have revealed relatively higher frequency and density, consequently higher degree on distribution and numerical strength of species in summer season on account of most sustainable climatic conditions. It seems in such natural communities, that constancy appears to depend on the balance between the stability and variability of the environment. The diversity of plant species decreases with altitude in the site. Soil electric conductivity, $\mathrm{pH}$, slope angle, slope exposure were found to be the highest environmental variables influencing the distribution of species and communities in the area.

It can be concluded that seasons have great effect on characteristics of soil and species diversity. It was observed that species diversity increases during spring and summer season which decreased later as autumn and winter come close which resulted in decline in the diversity due to dry environmental conditions, slow growth rate and other climatic factors. Difference in numerical parameters like, species richness and species diversity is correlated with variations in soil factors, slope aspect elevation, and micro-climatic conditions in different sites of the area.

Further it is concluded that the site faces the pressure from the local inhabitants in the form of overgrazing and deforestation, which have reduced regeneration of woody plants. Overgrazing, human population explosion, uprooting of medicinal plants by the local laypeople and other informal factors are responsible for habitat loss, soil erosion and proper functioning of ecosystems. There is dire need to conserve the biodiversity of the area in order to provide the resources and resource alternatives for the people's survival in the future.

It could be recommended that rare plant species in the specific micro-habitat can further be studied for conservation management purposes and future ethnobotanical projects must be initiated.

Author's Contributions. AZ conducted the fieldwork, collected data, plant species and conducted the herbarium work, SMK helped in the field work. AM identified the plants specimens. IUR drafted the manuscript. ZI and IUR analyzed the data, FI and MAK helped in organizing the data. ZI supervised the work. IUR and NA critically reviewed the manuscript, EFA, AAA, AH and AA helped in discussion. NA and IUR revised the manuscript, MS, YA and ESC helped in the revision. All the authors have read and approved the final manuscript.

Acknowledgements. The authors would like to extend their sincere appreciation to the Deanship of Scientific Research at King Saud University, Saudi Arabia for its funding to the Research Group number (RG-1435-014). 


\section{REFERENCES}

[1] Adnan, S. M. (2003): Feasibility of Community Involvement in the Sustainable Use of Medicinal Plants of Roringar Valley, Swat. - Ethnobotany Project WWFP, Peshawar.

[2] Ahmad, M., Sirajuddin (1996): Ethnobotanical Profile of Swat. - Proceedings of the First Training Workshop on Ethnobotany and its Application to Conservation, September 1624, PARC, WWF, ICIMOD, Islamabad, pp. 202-206.

[3] Ahmed, M., Khan, N., Wahab, M., Hamza, S., Siddiqui, M. F., Nazim, K., Khan, M. U. (2009): Vegetation structure of Olea ferruginea Royle Forests of lower Dir district of Pakistan. - Pak. J. Bot. 41(6): 2683-2695.

[4] Ajbilou, R. Maranon, T., Arroyyo, J. (2006): Ecological and biogeographical analyses of Mediterranean forests of northern Morocco. - Acta Ecologica 29: 104-113.

[5] Aleyha, M. Shokuii, M. (2003): Vegetation Types of Semnan Area. - Research Institute of Forests and Rangelands, Tehran, No. 335.

[6] Archibold, O. W. (1995): Ecology of World Vegetation (1st edition). - Chapman \& Hall, Great Britain.

[7] Asri, J. (1994): Phytosociology. - Forests and Rangelands Institute, Tehran, pp. 1-134.

[8] Bakkenes, M. Alkemade, J. R. Ihle, F. Leemans, R. Latour, J. B. (2002): Assessing effects of forecasted climate change on the diversity and distribution of European higher plants for 2050. - Glo. Change Bio. 8(4): 390.

[9] Bano, S., Khan, S. M., Alam, J., Alqarawi, A. A., Abd_Allah, E. F., Ahmad, Z., Hashem, A. (2018): Eco-Floristic studies of native plants of the Beer Hills along the Indus River in the districts Haripur and Abbottabad, Pakistan. - Saudi Journal of Biological Sciences 25(4): 801-810.

[10] Braun-Blanquet, J. (1983): Plant Sociology. - Koeltz Scientific Books, Königstein, pp. 35-72.

[11] Champion, H. G., Seth, S. K., Khattak, G. H. (1965): Forest Types of Pakistan. - Pak. Forest Int., Peshawar.

[12] Corney, M. G. Smart, S. M. Kibby, K. J., Buche, R. G. H., Marrs, R. H. (2006): Relationships between the species composition of forest field-layer vegetation and environmental drivers assessed using a national scale survey. - Journal of Ecology 94: 388-401.

[13] Dastagir, G. Haq, I. U., Malik, Z. H. (1999): Phytosociology of Mai Dhani Hill near Muzaffarabad, Azad Kashmir. - Pak. J. Bio. Sci. 2(2): 185-191.

[14] Dasti, A. A., Malik, S. A. A. (1998): A transect of vegetation and soils on the Indus valley scarp slope. - Pakistan. Pak J. Plant Sci. 4(2): 73-84.

[15] Daubenmire, R. (1959): Mountain topography and vegetation pattern. - North West Sci. 54(2): 146-152.

[16] El-Ghani, M. M. (1998): Environmental correlates of species distribution in arid desert ecosystems of eastern Egypt. - J. Arid Environ. 38: 297-313.

[17] Ewald, J. (2003): A critique for phytosociology. - J. Veg. Sci. 14(2): 291-296.

[18] Fallah Chay, M. M., Marvie Mohadjer, M. R. (2005): Ecological role of altitude in diversity of tree species in Siahkal forests, north of Iran. - Iranian J. Nat. Res. 58: 89-100 (in Persian).

[19] Goldsmith, F. B., Harrison, C. M., Morton, A. J. (1986): Description and Analysis of Vegetation. - In: Moore, P. D., Chapman, S. B. (eds.) Methods in Plant Ecology (2nd edition). The Alden Press, Oxford, pp. 437-534.

[20] Hanson, H., Churchill, E. D. (1965): The Plant Community. - Reinhold, New York, pp 219.

[21] Haq, F., Ahmad, H., Iqbal, Z. (2015a): Vegetation description and phytoclimatic gradients of sub-tropical forests of Nandiar Khuwar catchment District Battagram. - Pak. J. Bot. 47(4): 1399-1405. 
[22] Haq, F. Ahmad, H., Iqbal, Z. (2015b): Vegetation composition and ecological gradients of subtropical-moist temperate ecotonal forests of Nandiar Khuwar catchment, Pakistan. - Bangladesh J. Bot. 44(2): 267-276.

[23] Hussain, F. (1989): Field and laboratory manual of plants ecology. - University Grants Commission, Islamabad 3: 27-78.

[24] Karimi, G. H. H. (1997): Vegetation Cover of Anzali-Khalkhal Area. - Research Institute of Forests and Rangelands, Tehran.

[25] Kent, M., Coker, P. (1992): Vegetation Description and Analysis: A practical Approach. - John Wiley and Sons, New York.

[26] Khademi, A., Babaee, S. (2009): Investigation of biomass and its relation with physiographic and soil characteristics in oak forests. - Ir. J. Forest 1: 57-67.

[27] Khageaddin, H. (2000): Phytocociology of Kolahghazi National Park. - The Iranian Journal J. Pajouhesh \& Sazandegi 45: 10-16.

[28] Khan, S. M. Page, S., Ahmad, H., Shaheen, H., Harper, D. (2012): Vegetation dynamics in the western Western himalayasHimalayas, diversity indices and climate change. - Sci., Tech. and Dev. 31(3): 232-243.

[29] Khattak, N. S., Nouroz, F., Rahman, I. U., Noreen, S. (2015): Ethnoveterinary uses of medicinal plants of district Karak, Pakistan. - Journal of Ethnopharmacol. 171: 273-279.

[30] Koehler, F. E., Moudre, C. D., McNeal, B. L. (1984): Laboratory Manual for Soil Fertility. - Washington State University, Pulman, USA.

[31] Kumar, S. (1996): Trends in structural compositional attributes of duneinterdune vegetation and their edaphic relations in the Indian desert. Vegetatio 124: 73-93.

[32] Marvie, M. M. R. (1984): The study on Oak forest in Gorgan (case study; Loveh). Iranian J. Nat. Res. 37: 41-56 (in Persian).

[33] McLean, E. O. (1982): Soil pH and Lime Requirement. - In: Page, A. L., Miller, R. H., Keey, D. R. (eds.) Methods of Soil Analysis Part 2. Amer. Soc. Agron. No. 9, Madison, Wisconsin, USA, pp. 199-209.

[34] Mueller-Dumbois, D., Ellenberg, H. (1974): Aims and Methods of Vegetation Ecology. John Wiley and Sons, London, pp. 45-58.

[35] Nazarian, H. (2003): Eco-Phytosociological Evaluation of Elika and Dona Watershed of Central Alboorz. - PhD Thesis, Sciences Faculty, Tehran University.

[36] Nelson, D. W., Sommers, L. E., Sparks, D. L., Page, A. L., Helmke, P. A., Loeppert, R. H., Sumner, M. E. (1996): Total Carbon, Organic Carbon, and Organic Matter. - In: Sparks, D. L. (ed.) Methods of Soil Analysis. Part 3. Chemical Methods. American Society of Agronomy-Soil Science Society of America, Madison, WI, pp. 961-1010.

[37] Paul, A. E., Berry, E. H. (1921): The Kjeldahl method and its modifications. - J. Assoc. Agric. Chem. 5: 108-132.

[38] Rahman, I. U., Afzal, A., Iqbal, Z., Ijaz, F., Khan, S. M., Khan, S. A., Shah, A. H., Khan, K., Ali, N. (2015): Influence of foliar nutrients application on growth and yield of onion grown in nutrient deficient soil. - Bangladesh J. Bot. 44: 613-619.

[39] Rahman, I. U., Ijaz, F., Afzal, A., Iqbal, Z., Ali, N., Khan, S. M. (2016a): Contributions to the phytotherapies of digestive disorders. Traditional knowledge and cultural drivers of Manoor Valley, Northern Pakistan. - J. Ethnopharmacol. 192: 30-52.

[40] Rahman, I. U., Ijaz, F., Afzal, A., Iqbal, Z., Ali, N., Afzal, M., Khan, M. A., Muhammad, S., Qadir, G., Asif, M. (2016b): A novel survey of the ethno medicinal knowledge of dental problems in Manoor Valley (Northern Himalaya). - Pakistan. J. Ethnopharmacol. 194: 877-894.

[41] Rahman, I. U., Ijaz, F., Afzal, A. Iqbal, Z. (2017): Effect of foliar application of plant mineral nutrients on the growth and yield attributes of chickpea (Cicer arietinum L.) Under nutrient deficient soil conditions. - Bangladesh J. Bot. 46: 111-118.

[42] Rahman, I. U., Afzal, A., Iqbal, Z. et al. (2018): First insights into the floristic diversity, biological spectra and phenology of Manoor Valley, Pakistan. - Pak. J. Bot. 50: 11131124. 
[43] Saima, S., Dasti, A. A., Hussain, F., Wazir, S. M., Malik, S. A. (2009): Floristic compositions along an 18 - km long transect in Ayubia National Park district Abbottabad, Pakistan. - Pak. J. Bot. 41(5): 2115-2127.

[44] Shaheen, S., Iqbal, Z., Ijaz, F., Alam, J., Rahman, I. U. (2016): Floristic composition, biological spectrum and phenology of Tehsil Havelian, District Abbottabad, Pakistan. Pak. J. Bot. 48(5): 1849-1859.

[45] Soltanpour, P. N. (1985): Use of ammonium bicarbonate DTPA soil test to evaluate elemental availability and toxicity. - Commun. Sci. Pl. Anal. 16: 323-338.

[46] Sorenson, T. (1948): A method of establishing groups of equal amplitude in plant sociology based on similarity of species and its application to analyses of the vegetation on Danish commons. - Royal Danish Academy of Sciences and Letters 5(4): 1-34.

[47] Ter Braak, C. J. F. (1986): Canonical correspondence analysis: A new eigenvector technique for multivariate direct gradient analysis. - Ecol. 67: 1167-1179.

[48] Ter Braak, C. J. F. (1994): Canonical community ordination. Part I: Basic theory and linear methods. - Ecoscience 1: 127-140.

[49] Zhang, K., Dang, H., Tan, S., Wang, Z., Zhang, Q. (2010): Vegetation community and soil characteristics of abandoned agricultural land and pine plantation in the Qinling Mountains, China. - Forest Ecol. Manag. 259: 2036-2047.

[50] Zhanghe, C., Jieyuan, C., Yunlong, Z. (1999): Flowering and fruiting phenologies of the woody plants in three floras in China. - J. Trop. Subtrop. Bot. 7: 102-108. 